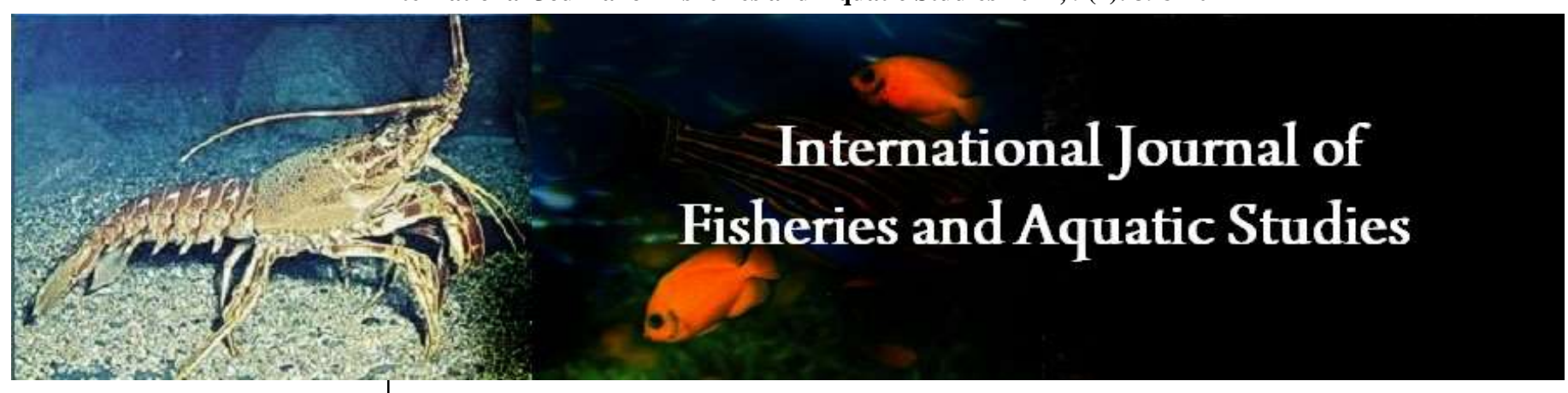

E-ISSN: 2347-5129

P-ISSN: 2394-0506

(ICV-Poland) Impact Value: 5.62

(GIF) Impact Factor: 0.549

IJFAS 2021; 9(1): 398-402

(C) 2021 IJFAS

www.fisheriesjournal.com

Received: 05-11-2020

Accepted: 17-12-2020

Paul Mamadou Ndour

Faculté des Sciences et Techniques,

Université Cheikh Anta Diop de

Dakar (UCAD), Dakar, Sénégal, BP: 5005

\section{Jean Fall}

Institut Universitaire de Pêche et

d'Aquaculture, UCADII Bâtiment

Pédagogique, Rez de chaussée,

Sénégal, BP: 5005

\section{Abdoulaye Loum}

Département Aquaculture, Université

Gaston Berger Saint-Louis, Sénégal

Mariama Sagne

Institut Universitaire de Pêche et

d'Aquaculture, UCADII Bâtiment

Pédagogique, Rez de chaussée,

Sénégal, BP: 5005

Ndèye Fatou Diagn

Institut Universitaire de Pêche et d'Aquaculture, UCADII Bâtiment

Pédagogique, Rez de chaussée,

Sénégal, BP: 5005

\section{Seydy Moustapha Samb}

Institut Universitaire de Pêche et

d'Aquaculture, UCADII Bâtiment

Pédagogique, Rez de chaussée,

Sénégal, BP: 5005

\section{Diégane Ndong}

Direction des Ressources Animales et

Halieutiques, Département de

l'Agriculture, des Ressources en Eau et de l' Environnement, Commission de l' UEMOA, 380 Av. Pr. Joseph

KI ZERBO, 01 BP 543 Ouagadougou

01 Burkina Faso

\section{Malick Diou}

Institut Universitaire de Pêche et d'Aquaculture, UCADII Bâtiment Pédagogique, Rez de chaussée,

Sénégal, BP: 5005
Corresponding Author: Paul Mamadou Ndour Faculté des Sciences et Techniques, Université Cheikh Anta Diop de Dakar (UCAD), Dakar, Sénégal, BP: 5005

\section{Effects of Kigelia africana, Beta vulgaris and Ricinodendron heudelotti as feed additive on growth performance, survival and whole-body composition of Nile tilapia (Oreochromis niloticus) Linnaeus, 1758) fry}

\author{
Paul Mamadou Ndour, Jean Fall, Abdoulaye Loum, Mariama Sagne, \\ Ndèye Fatou Diagne, Seydy Moustapha Samb, Diégane Ndong and Malick \\ Diouf
}

DOI: https://doi.org/10.22271/fish.2021.v9.i1e.2426

\begin{abstract}
The effect of three African medicinal herbs used as feed additive on the growth and survival of Nile tilapia (Oreochromis niloticus) was studied. Four isoproteins (32\%) and isolipid (13\%) diets, namely RC (control diet or $0 \%$ plant), 3\% B. vulgaris, 3\% K. africana and 3\% R. heudelotti, were manufactured. One hundred and eighty (180) Nile tilapia fry with an initial average weight of $0.15 \pm 0.01 \mathrm{~g}$ were randomly distributed in 12 plastic tanks (50 L / tank) at a density of 15 fish per tank and fed three times $(8.00 \mathrm{~h} \mathrm{am}$, $1.00 \mathrm{~h} \mathrm{pm}$ and $5.00 \mathrm{~h} \mathrm{pm}$ ) per day for 90 days. For the parameters studied (average weight gain (AWG), feed conversion ratio (FCR), specific growth rate (SGR) and survival rate (SR)) no significant difference was observed between diets at the end of the experiment. Furthermore, the addition of $3 \% \mathrm{~K}$. africana or $B$. vulgaris or $R$. heudelotti had no impact on the dry matter, ash, crude protein and whole-body fat content of Nile tilapia fry. This study showed that $3 \%$ B. vulgaris or K. africana or R. heudelotti has no adverse effect on the growth, survival and whole-body composition of Nile tilapia fry.
\end{abstract}

Keywords: Kigelia africana, Beta vulgaris, Ricinodendron heudelotti, additives, growth, whole-body composition

\section{Introduction}

The Nile tilapia (Oreochromis niloticus L., 1758), a species of the family Cichlidae, is one of the major freshwater fish species produced in the world ${ }^{[1]}$. The intensification of aquaculture systems has triggered the occurrence of many diseases. On the other hand, antibiotics use has caused many issues such spread of drug-resistant pathogens, suppression of aquatic animal immunity, and adverse environmental effects ${ }^{[2]}$. In this respect, measures to reduce and develop alternatives are becoming a priority for international organizations (FAO, WHO, OIE, EFSA). For these reasons, the aquaculture industry's interest in plant resources is increasing day by day ${ }^{[3]}$. Plant products stimulate growth rate and immunity due to active compounds such as alkaloids, terpenoids, saponins and flavonoid components ${ }^{[4]}$. The World Health Organization also encourages the use of herbs and medicinal plants to replace or minimize the use of chemicals. Herbal additives can be used for phytotherapy, immunostimulant effect and growth promoter in aquaculture ${ }^{[5]} . R$. heudelotti is a tree of the Euphorbiaceae family that can reach a height of $50 \mathrm{~m}$ and a circumference of $2.7 \mathrm{~m}$ on average. The seed powder of $R$. heudelotti contains $31.4 \%$ protein and $44.7 \%$ lipids, of which $73 \%$ are polyunsaturated ${ }^{[6]}$. It is one of the most widely used plants in therapeutics since ancient times. In Africa, it is used for its anti-inflammatory, antimicrobial, and anti-aging skin effects. Studies by Olasehinde et al. ${ }^{\text {[7] }}$ showed that $R$. heudelotti nuclei's essential oil has phytochemical compounds and metals of medicinal importance. Beet (Beta vulgaris L.) is a herbaceous plant belonging to the Chenopodiaceae family. It is famous for its juice value and medicinal properties ${ }^{[8]}$. The chemical and mineral composition shows that the moisture content was $87.4 \%$, fat $0.3 \%$, protein $1.35 \%$, carbohydrates $7.59 \%$, crude fiber $1.9 \%$ and ash $1.4 \%{ }^{[9]}$. The beet could be incorporated up to $300 \mathrm{~g} / \mathrm{kg}$ without changing the growth and feed efficiency parameters of Tilapia Nile (Oreochromis niloticus) ${ }^{[10]}$. 
It is an excellent dietary supplement rich in minerals, nutrients and vitamins. It has unique phytoconstituents, which have several medicinal properties. Kigelia africana (Lam Benth) is a plant from tropical Africa widely grown and distributed throughout central, southern and western Africa. It belongs to the family Bignoniaceae. In Malawi, the seeds are roasted for human consumption ${ }^{[11]}$. These seeds are potentially rich in certain essential fatty acids such as linolenic and linoleic acids ${ }^{[12]}$. K. africana is an antioxidant, and these phytochemicals, nutritional and mineral constituents make $K$. africana an interesting plant that can be used to cure many diseases and as a food additive ${ }^{[13]}$. The objective of this study was to evaluate the impact of $K$. africana, B. vulgaris and $R$. heudelotti as feed additive on the growth performance, survival and wholebody composition of Nile tilapia (O. niloticus) fry.

\section{Material and Methods \\ Medicinal plants}

The medicinal plants such as $K$. africana, B. vulgaris and $R$. heudelotti were selected on the basis of scientific literature. The seed powders $K$. africana and $R$. heudelotti and the roots of $B$. vulgaris were purchased from the local market. The roots of $B$. vulgaris was washed, pressed, dried and processed into powder in the IUPA experimental unit. The powders were stored in glass jars until their use.

\section{Experimental diets}

The diets were formulated to be isonitrogenic (32\% CP) and isolipidic (13\% CL). One control diet and three test diets were manufactured. The control diet and the three test diets, i.e. 3\% B. vulgaris, $3 \% \mathrm{~K}$. africana and $3 \% \mathrm{R}$. heudelotti, were manufactured to obtain $1 \mathrm{~kg}$ of feed. The composition of the different diets is recorded in (Table 1).

After pre-treatment of the ingredients (removing certain impurities), they were weighed according to the diet composition (Table 1) and mixed. $30 \%$ of water was added to the mixture to obtain malleable dough. This dough was transformed by a grinder (Moulinex) into filaments like spaghetti. The diets were dried in an artisanal dryer for $1 \mathrm{~h}$ at $36{ }^{\circ} \mathrm{C}$. These dried filaments were grounded to powder using a mortar before being packaged in glass jars for fry feeding.

\section{Study environment and fish feeding}

The study was conducted in the University Institute of Fisheries and Aquaculture (IUPA) experimental unit at the Cheikh Anta Diop University of Dakar (UCAD). One hundred and eighty (180) Nile tilapia fry with an initial mean weight of $0.15 \pm 0.01 \mathrm{~g}$ were randomly assigned to 12 plastic tanks (50 L / tank) at the density of 15 fish per tank in an isolated system. At the beginning of the test, the weight of each fish was taken. The fish fasted $24 \mathrm{~h}$ before weighing. Each tank was equipped with an air pump for the oxygenation of the water. The tanks were cleaned daily to remove fecal matter and any leftover feed.

The experimental fish, divided into four batches, were fed with the four diets. They were fed manually during 90 days of experimentation at $15 \%$ of their biomass three times a day $(8.00 \mathrm{~h}$ am, $1.00 \mathrm{~h} \mathrm{pm}$, and $5.00 \mathrm{~h} \mathrm{pm})$. The quantities of feed distributed to the fish were readjusted after each sampling according to the biomass's evolution.

\section{Growth parameters, survival and feed efficiency}

Sampling was carried out every 15 days by weighing each fish. At the end of the experiment, all fish were individually weighed using a scale to determine average weight gain (AWG (g)), specific growth rate (SGR (\%/day)), feed conversion ratio (FCR) and survival rate (SR (\%)). The equations used to calculate the results for each parameter were as follows:

- $\quad$ AWG $(\mathrm{g})=\mathrm{Wf}-\mathrm{Wi}$;

- $\operatorname{SGR}(\% /$ day $)=100 *(\ln W f-\ln W i) / T$;

- $\quad \mathrm{FCR}=$ Total dry weight of diet fed $(\mathrm{g}) /$ weight gain $(\mathrm{g})$;

- $\quad \mathrm{SR}=$ (number of final fish / number of initial fish $) * 100$.

where Wf and Wi are respectively the final average weight and the initial average weight and $\mathrm{T}=$ time in days.

\section{Chemical analysis of experimental diets}

Samples of $K$. africana and $R$. heudelotti seed powder, $B$. vulgaris roots powder and the experimental diets were sent to the laboratory for biochemical analysis to determine their composition (dry matter, crude protein, ash, and fat). After the feeding trial, the whole body of the fish fed the different diets was freeze-dried and analyzed for dry matter, crude protein, ash and fat content.

The analysis was based on the Association of Official Analytical Chemists (AOAC) procedure. Samples of fish feed and fish muscle were dried to a constant weight at $103{ }^{\circ} \mathrm{C}$ for $24 \mathrm{~h}$ to determine the moisture content and consequently the dry matter values were determined. Crude protein (total nitrogen $x$ 6.25) was determined using the Kjeldahl method. Fat was determined by the Randall method (extraction of fat with petroleum ether) with prior hydrolysis. The ash was determined by incineration of samples in a muffle furnace at $550{ }^{\circ} \mathrm{C}$ for $4 \mathrm{~h}$.

\section{Statistical Analysis}

Microsoft Excel was used to enter and calculate the data. The analysis of these data was carried out with the Statistical Analysis System software (SAS-PC) ${ }^{[14]}$ subjected to an analysis of variance (ANOVA). The results were presented as means of the three replicates. The Duncan test was used to compare significant differences between treatments. The difference was considered significant at $\mathrm{P}$-values $<0.05$.

Table 1: Gross composition of experimental diets per kilogram

\begin{tabular}{|c|c|c|c|c|}
\hline \multirow[b]{2}{*}{ Ingredients (g) } & \multicolumn{4}{|c|}{ Experimental diets } \\
\hline & \begin{tabular}{|c|} 
Contro \\
1
\end{tabular} & $\begin{array}{c}\text { 3\% K. } \\
\text { africana }\end{array}$ & $\begin{array}{c}3 \% B . \\
\text { vulgaris }\end{array}$ & $\begin{array}{c}3 \% R . \\
\text { heudelotti }\end{array}$ \\
\hline B. vulgaris & \begin{tabular}{|l|}
0 \\
\end{tabular} & 30 & 0 & 0 \\
\hline K. africana & 0 & 0 & 30 & 0 \\
\hline R. heudelotti & 0 & 0 & 0 & 30 \\
\hline Fish meal & 320 & 320 & 320 & 320 \\
\hline Millet bran meal & 200 & 200 & 200 & 200 \\
\hline Rice bran meal & 100 & 100 & 100 & 100 \\
\hline Fish oil & 50 & 50 & 50 & 50 \\
\hline Corn flour & 250 & 220 & 220 & 220 \\
\hline S. cerevisiae & 40 & 40 & 40 & 40 \\
\hline Gum Sterculia & 20 & 20 & 20 & 20 \\
\hline Mineral premix ${ }^{\mathbf{a}}$ & 10 & 10 & 10 & 10 \\
\hline Vitamins premix $^{\mathbf{b}}$ & 10 & 10 & 10 & 10 \\
\hline Total $(\mathrm{g})$ & 1000 & 1000 & 1000 & 1000 \\
\hline
\end{tabular}

$\mathbf{a}=$ phosphorus $7 \%$; calcium $17 \%$; sodium $1.5 \%$; potassium $4.6 \%$; $7.5 \%$ magnesium; manganese $738 \mathrm{mg}$; $3000 \mathrm{mg}$ zinc; $4000 \mathrm{mg}$ iron; $750 \mathrm{mg}$ copper; iodine $5 \mathrm{mg}$; cobalt $208 \mathrm{mg}$; calcined and ground attapulgite qs $1000 \mathrm{~g}$; fluorine content of the complex $1.5 \%$ (approximately), dose $1 \mathrm{~kg}$ per $100 \mathrm{~kg}$ of food.

b = lives at $250000 \mathrm{IU}$; lives D3 250000UI; lives E 5000mg; lives B1 100mg; lives B2 400mg; lives B3 (pp) 1000mg; saw B5 pentode Ca2000mg; lives B6 300mg; lives K3 1000g; saw C 5000mg; H biotin 15mg; choline 100g; special expiant (anti oxidant (BHT), attapulgite crushed and calcined) qs $1000 \mathrm{mg}$. 
Table 2: Chemical composition of $K$. africana and $R$. heudelotti seed powder and $B$. vulgaris roots powder

\begin{tabular}{|c|c|c|c|c|}
\hline Additives & $\begin{array}{c}\text { Dry matter } \\
(\boldsymbol{\%})\end{array}$ & $\begin{array}{c}\text { Ash } \\
(\boldsymbol{\%})\end{array}$ & $\begin{array}{c}\text { Crude } \\
\text { protein (\%) }\end{array}$ & $\begin{array}{c}\text { Fat } \\
(\boldsymbol{\%})\end{array}$ \\
\hline B. vulgaris & 82.00 & 11.09 & 13.98 & 0.63 \\
\hline K. africana & 90.24 & 16.51 & 18.31 & 3.12 \\
\hline R. heudelotti & 90.29 & 8.52 & 27.83 & 3.87 \\
\hline
\end{tabular}

\section{Results}

The survival rate was above $98 \%$ in all experimental groups and no significant difference between treatments was detected $(P>0.05)$. Water temperature was monitored daily and ranged from 24.4 to $26.5^{\circ} \mathrm{C}$.

At the end of the experiment, parameters such as average weight gain (AWG), specific growth rate (SGR), feed conversion ratio (FCR) and survival rate (SR) were determined for each treatment. The ANOVA treatment of the different parameters studied didn't show any significant difference $(P>0.05)$ between treatments (Table 3$)$.

Table 3: Growth performance and feed efficiency parameters of Nile tilapia fry fed experimental diets

\begin{tabular}{|c|c|c|c|c|}
\hline \multirow{2}{*}{$\begin{array}{c}\text { Experimental } \\
\text { diets }\end{array}$} & \multicolumn{4}{|c|}{ Parameters } \\
\cline { 2 - 5 } & AWG (g) & $\begin{array}{c}\text { SGR } \\
(\% / d)\end{array}$ & FCR & $\begin{array}{c}\text { SR } \\
(\%)\end{array}$ \\
\hline Control & $2.28 \pm 0.51$ & $4.89 \pm 0.07$ & $1.43 \pm 0.01$ & 100.00 \\
\hline $3 \%$ K. africana & $2.21 \pm 0.22$ & $4.88 \pm 0.19$ & $1.50 \pm 0.05$ & 100.00 \\
\hline $3 \%$ B. vulgaris & $2.11 \pm 0.04$ & $4.77 \pm 0.02$ & $1.47 \pm 0.04$ & 100.00 \\
\hline $3 \%$. heudelotti & $2.11 \pm 0.09$ & $4.81 \pm 0.09$ & $1.49 \pm 0.01$ & 98.00 \\
\hline
\end{tabular}

AWG (g): average weight gain; SGR (\%/d): specific growth rate; FCR: feed conversion ratio; RS: survival rate

The chemical composition of the different diets, i.e. the control diets, 3\% K. africana, 3\% R. heudelotti and 3\% B. vulgaris is shown in (Table 4). No significant effect was observed following the addition of $3 \% \mathrm{~K}$. africana or $B$. vulgaris or $R$. heudelotti on dry matter and ash contents. A slight increase in protein content and a slight decrease in fat content was observed following the addition of $3 \% \mathrm{~K}$. africana compared to the control diet.

Table 4: Chemical composition of the different experimental diets

\begin{tabular}{|c|c|c|c|c|}
\hline $\begin{array}{c}\text { Experimental } \\
\text { Diets }\end{array}$ & $\begin{array}{c}\text { Dry matter } \\
(\mathbf{\%})\end{array}$ & $\begin{array}{c}\text { Ash } \\
(\mathbf{\%})\end{array}$ & $\begin{array}{c}\text { Crude } \\
\text { protein (\%) }\end{array}$ & $\begin{array}{c}\text { Fat } \\
(\mathbf{\%})\end{array}$ \\
\hline Control & 89.93 & 9.49 & 30.00 & 12.30 \\
\hline 3\% K. africana & 90.48 & 9.60 & 32.15 & 11.90 \\
\hline 3\% B. vulgaris & 91.56 & 9.96 & 30.06 & 12.24 \\
\hline 3\% R. heudelotti & 91.17 & 10.09 & 31.52 & 12.44 \\
\hline
\end{tabular}

The results drawn from the whole body chemical analysis of tilapia fry fed the experimental diets are shown in Table 5. The results showed that the levels of dry matter in the whole bodies of the fry fed the diets containing $3 \%$ additive, i.e., $3 \%$ $K$. africana or $3 \%$ B. vulgaris or $3 \% R$. heudelotti were significantly different from that of the tilapia fry fed the control diet (without additive). The $3 \% \mathrm{~B}$. vulgaris and $3 \% \mathrm{R}$. heudelotti diets slightly increased the dry matter, crude protein and fat contents and slightly decreased the whole body ash content of tilapia fry compared to the whole body of fry fed the control diet (without additives). The ash content of the whole bodies of the fry fed the diets containing $3 \%$ additive, i.e., $3 \% R$. heudelotti or $3 \%$ B. vulgaris were lower that of fish fed the control diet. The Ash content of the whole bodies of the fry fed the diets containing $3 \% \mathrm{~K}$. africana were not significantly different from the fish fed the control diet. The crude protein of the whole bodies of the fry fed with additives increased compared to that of fish fed with the control diet. The whole body crude protein of the fish fed diet containing $3 \% K$. africana was higher than that of fish fed $3 \% R$. heudelotti or $3 \%$ B. vulgaris and the control. The crude protein content of the fish fed with $3 \% R$. heudelotti was not significantly different from the fish fed with the control diet. The fat content of fish fed with the diets containing $3 \% R$. heudelotti or $3 \%$ B. vulgaris was not different from the fish fed with the control diet. The fat content of fish fed with the diet containing $3 \% \mathrm{~K}$. africana was not different from the fish fed with the control diet.

Table 5: Whole body chemical composition of Nile tilapia fry fed experimental diets

\begin{tabular}{|c|c|c|c|c|}
\hline $\begin{array}{c}\text { Experimental } \\
\text { diets }\end{array}$ & $\begin{array}{c}\text { Dry } \\
\text { matter } \\
(\mathbf{\%})\end{array}$ & $\begin{array}{c}\text { Ash } \\
\mathbf{( \% )}\end{array}$ & $\begin{array}{c}\text { Crude } \\
\text { protein }(\boldsymbol{\%})\end{array}$ & $\begin{array}{c}\text { Fat } \\
(\mathbf{\%})\end{array}$ \\
\hline Control & 90.2 & 15.9 & 55.9 & 19.8 \\
\hline 3\% K. africana & 91.5 & 16.7 & 60.1 & 17.3 \\
\hline 3\% B. vulgaris & 91.6 & 14.3 & 57.4 & 20.8 \\
\hline 3\% R. heudelotti & 91.3 & 14.1 & 56.4 & 21.0 \\
\hline
\end{tabular}

\section{Discussion}

The results of the present study showed no significant difference $(P>0.05)$ for the growth and feed efficiency parameters, i.e., average weight gain (AWG), specific growth rate (SGR); feed conversion ratio (FCR) and survival rate (SR) for the different treatments. The results of the chemical analysis also showed no significant difference between treatments. The recorded FCRs are in the range (1.4-2.4), which is optimal for farmed tilapia ${ }^{[15]}$. According to Ahmad and Abdel-Tawwab ${ }^{[16]}$, argued that FCR could measure fish production efficiency. SRs greater than $98.5 \%$ suggested that supplementation with $3 \% \mathrm{~B}$. vulgaris or $K$. africana or $R$. heudelotti in the basal diet has no toxic effect on Nile tilapia fry according to Jha et al. ${ }^{[17]}$ who argued, based on their results on survival rate between 98.5 and $100 \%$, that $20 \mathrm{~g}$ of cumin seed meal as a feed additive per kilogram of feed had no toxic effect on $O$. niloticus fry. This study's results are similar to the findings of Jha et al. ${ }^{[18]}$ following the addition of $3 \%$ B. vulgaris in the diet of Barilius Bendelisis. In addition, 3\% B. vulgaris does not affect growth parameters such as weight gain and specific growth rate of Schizothorax richardsonii fry ${ }^{[19]}$. Also, incorporation of up to $300 \mathrm{~g} / \mathrm{kg}$ of B. vulgaris fodder beets had no negative effect on feed conversion ratio (FCR), specific growth rate (SGR) and weight gain (WG) ${ }^{[20]}$. $K$. africana seed powder could be incorporated up to $100 \mathrm{~g} / \mathrm{kg}$ wit hout affecting the growth and survival of Clarias gariepinus ${ }^{[21]}$. This study's results are similar to that of Ahmadifar et al. ${ }^{[22]}$, who showed that supplementation up to $200 \mathrm{mg} / \mathrm{kg}$ of Tetracarpidium conophorum seed powder as a dietary supplement on the reproductive indices of male Clarias gariepinus broodstock has no negative effect on growth and survival. Furthermore, ginger powder supplementation of up to $3 \%$ for eight weeks has no negative effect on the growth (RMS and weight gain) and survival of zebrafish (Danio rerio) ${ }^{[23]}$. The addition of 3\% Black Garlic Seed and Commercial Biogenes to the diets of Nile Tilapia ( $O$. niloticus) also showed no significant difference in growth performance between the different diets implemented [24]. The results of this study are similar to the work of Ekanem et al. ${ }^{[25]}$, who added $70 \mathrm{~g}$ of S. jamaicensis 
leaf meal and $35 \mathrm{~g}$ of $G$. kola $+35 \mathrm{~g}$ of $S$. jamaicensis leaf meal in the diet of Clarias gariepinus. They showed no significant difference $(P>0.05)$ for weight gain, SGR and FCR between treatments. According to El-Dakar [26], most spices and herbs can be considered non-nutritive feeds because of their small amounts used in fish feed. The composition of the diets in this study is similar to that of Hassan et al. [27] although the lipid contents are more important in our study. Lipid contents in the present study are in the range of dietary lipid requirements for tilapia (10-15\% dry matter) ${ }^{[28-30]}$. Whole-body chemical analyses of Nile tilapia fry in this study to determine the influence of the experimental diets on dry matter, crude protein, fat, and ash content did not show significant differences between treatments. This study's results are similar to the findings of Mathew et al. ${ }^{[31]}$, which showed that the incorporation of $3 \%$ Phoneix dactylifera seed powder does not affect the body composition (dry matter, protein, ash, and fat) of Nile tilapia.

\section{Conclusion}

The results of this study show that supplementation of $3 \% \mathrm{~g}$ of B. vulgaris or $3 \%$ of $K$. africana or $3 \%$ of $R$. heudelotti in one kilogram of basal diet does not alter the parameters of growth (AWG, SGR and FCR), survival and whole-body composition of Nile tilapia fry. However, further research could be implemented to explore the serological and immunological parameters of Nile tilapia fed with a diet containing B. vulgaris or K. africana, or R. heudelotti.

\section{Reference}

1. The State of World Fisheries and Aquaculture. Sustainability in action. Rome 2020.

2. Allameh SK, Yusoff FM, Ring $\varnothing$ E, Daud HM, Saad CR, Ideris A. Effects of dietary mono-and multiprobiotic strains on growth performance, gut bacteria and body composition of Javanese carp (Puntius gonionotus, B leeker 1850). Aquaculture nutrition 2016;22(2):367-373.

3. Dikel S. The use of garlic (Allium sativum) as a growth promoter in aquaculture. Turkish Journal of AgricultureFood Science and Technology 2015;3(7):529-536

4. Reverter M, Tapissier-Bontemps N, Sasal P, Saulnier D. Use of medicinal plants in aquaculture. In: Austin, B., Newaj-Fyzul, A. (Eds.), Diagnosis and Control of Diseases of Fish and Shellfish. JohnWiley \& Sons Ltd, New Jersey. 2017, 223-261.

5. Dikel S. Su Ürünleri Yetiştiriciliğinde Bitkisel Katki Maddeleri. Veterinerlik ve Su Ürünleri Araştırmaları I. Akademisyen Kitabevi. Sayfa 2019, 81-93.

6. Ezekwe MO, Besong SA, Johnson R. Nutritive composition of omega-3 fatty acids-rich Ricinodendron heudelotii and its potential for nutrition. International Journal of Nutrition and Metabolism 2014;6(6):56-62.

7. Olasehinde GI, Akinlabu DK, Owoeye FT, Owolabi EF, Audu OY, Mordi RC. Phytochemical and Antimicrobial Properties of Oil Extracts from the Seeds of Ricinodendron heudelotii. Research Journal of Medicinal Plants 2016;10(5):362-365.

8. Yashwant K. Beetroot: A Super Food. International Journal of Engineering Studies and Technical Approach. 2015;1(3):20-26

9. Kale RG, Sawate AR, Kshirsagar RB, Patil BM, Mane RP. Studies on evaluation of physical and chemical composition of beetroot (Beta vulgaris L.) International Journal of Chemical Studies 2018;6(2):2977-2979
10. Belal I. Incorporating fodder beet Beta vulgaris cv. Majoral in Nile tilapia Oreochromis niloticus (L.) diet. Emir J Food Agric 2007;19(1):22-30.

11. Semwal DK, Semwal RB, Ahmad A, Kamatou GP, Viljoen AM. Inhibitory Effects of Extracts and Isolates from Kigelia africana Fruits against Pathogenic Bacteria and Yeasts. Int J Pharmacol Pharm Sci 2014;8(12):13211326.

12. Oseni OA, Williams OD. In-vitro compositional investigations of antioxidants, phytochemicals, nutritional, and minerals in the fruit of Kigelia africana (Lam.) Benth. International Journal of Contemporary Research and Review 2018;9(8):20259-20268.

13. Joyner SP. SAS/STAT Guide for Personal Computer, Statistical Analysis System Institute, Cary, NC, USA.1985.

14. Fry JP, Mailloux NA, Love DC, Milli MC, Cao L. Feed conversion efficiency in aquaculture : Do we measure it correctly? Environmental Research Letters 2018;13(2):024017.

15. de Verdal H, Komen H, Quillet E, Chatain B, Allal F, Benzie JAH et al. Improving feed efficiency in fish using selective breeding: a review. Rev Aquacult 2018; 10(4):833-851.

16. Ahmad MH, Abdel-Tawwab M. The use of caraway seed meal as a feed additive in fish diets: Growth performance, feed utilization, and whole-body composition of Nile tilapia, Oreochromis niloticus (L.) fingerlings. Aquaculture 2011;314(1-4):110-114.

17. Jha GN, Sarma D, Qureshi TA, Jha T. Effect of Beetroot (Beta Vulgaris) and Apple (Pyrus Malus) Peel Fortified Diets on Growth, Body Composition and Total Carotenoid Content of Barilius Bendelisis. Indian J Anim Nutr 2013;30(3):299-303.

18. Jha GN, Sarma D, Qureshi TA, Akhtar MS. Effect of Marigold Flower and Beetroot Meals on Growth Performance, Carcass Composition, and Total Carotenoids of Snow Trout (Schizothorax richardsonii). The Israeli Journal of Aquaculture 2012;64:752-761.

19. Belal I. Incorporating fodder beet Beta vulgaris cv. Majoral in Nile tilapia Oreochromis niloticus (L.) diet. Emir J Food Agric 2007;19(1):22-30.

20. Adeparusi EO, Dada AA, Alale OV. Effects of Medicinal Plant (Kigelia africana) on Sperm quality of African catfish Clarias gariepinus (Burchel, 1822) Broodstock. JAS 2010;2(1):193-199.

21. Adekunle D, Oluwafunmilayo A. Dietary effects of African walnut (Tetracarpidium conophorum) on the reproductive indices in male African catfish (Clarias gariepinus) broodstock. J Coast Life Med 2015;3(6):471475.

22. Ahmadifar E, Sheikhzadeh N, Roshanaei K, Dargahi N, Faggio C. Can dietary ginger (Zingiber officinale) alter biochemical and immunological parameters and gene expression related to growth, immunity and antioxidant system in zebrafish (Danio rerio)? Aquaculture 2019;507:341-348.

23. Diab AS, Aly SM, John G, Abde-Hadi Y, Mohammed MF. Effect of garlic, black seed and Biogen as immunostimulants on the growth and survival of Nile tilapia, Oreochromis niloticus (Teleostei: Cichlidae), and their response to artificial infection with Pseudomonas fluorescens. African Journal of Aquatic Science 2008;33(1):63-68. 
24. Ekanem SB, Eyo VO, Okon EE. The effects of Brazilian tea (Stachytarpheta jamaicensis) and Bitter kola (Garcinia kola) seed meal on the growth and gonad development of the African catfish Clarias gariepinus (Burchell, 1822). Ege Journal of Fisheries and Aquatic Sciences 2017;34(2):179-185.

25. Ekanem SB, Eyo VO, Okon EE. The effects of Brazilian tea (Stachytarpheta jamaicensis) and Bitter kola (Garcinia kola) seed meal on the growth and gonad development of the African catfish Clarias gariepinus (Burchell, 1822). Ege Journal of Fisheries and Aquatic Sciences 2017;34(2):179-185.

26. El-Dakar A. Use of medical and aromatic plants in fish diets: 2. Effect of dried basil leaves on performance of hybrid tilapia Oreochromis niloticus $\times$ O. aureus, fingerlings. In: 3rdInternational Conference on Animal Production and Health in semi-Arid Areas, Suez Canal University 2004.

27. Hassan AAM, Yacout MH, Khalel MS, Hafsa SHA, Ibrahim MAR, Mocuta DN et al. Effects of Some Herbal Plant Supplements on Growth Performance and the Immune Response in Nile Tilapia (Oreochromis Niloticus). "Agriculture for Life, Life for Agriculture" Conference Proceedings 2018;1(1):134-141.

28. Chou BS, Shiau SY. Optimal dietary lipid level for growth of juvenile hybrid tilapia, Oreochromis niloticus x Oreochromis aureus. Aquaculture 1996;143(2):185195.

29. He AY, Ning LJ, Chen LQ, Chen YL, Xing Q, Li J et al. Systemic adaptation of lipid metabolism in response to low- and high-fat diet in Nile tilapia (Oreochromis niloticus). Physiological Reports 2015;3(8):1-18.

30. Kefi A, Kang'ombe J, Kassam D, Katongo C. Optimal Dietary Plant Based Lipid on Growth of Oreochromis andersonii (Castelnau, 1861). Turkish Journal of Fisheries and Aquatic Sciences 2013;13(3):503-508.

31. Mathew RT, Alsaqufi AS, Al-Ngada RS. Evaluation of date (Phoneix dactylifera) seed powder as dietary additive for nile Tilapia, Oreochromis niloticus L. Anim Nutr and Feed Tech 2020;20(2):231-242. 